Rev. Int. Contam. Ambie. 37, 401-417, 2021

https://doi.org/10.20937/RICA.54215

\title{
ARSENIC AND LEAD BIOACCESSIBILITIES MEASURED WITH A NOVEL REACTOR SYSTEM USING THE MEXICAN STANDARD AND PBET METHODS: COMPARISON WITH IN VIVO AND IN VITRO REPORTED DATA
}

\author{
Bioaccesibilidad de arsénico y plomo determinada con un novedoso sistema de reactores usando \\ el método PBET y el de la Norma Oficial Mexicana: comparación con datos reportados in vivo e in vitro \\ Thalía GARCÍA-RODRÍGUEZ, Margarita Eugenia GUTIÉRREZ-RUIZ* \\ and Águeda Elena CENICEROS-GÓMEZ
}

Laboratorio de Biogeoquímica Ambiental, Facultad de Química, Universidad Nacional Autónoma de México, Ciudad Universitaria, Av. Universidad No. 3000, Coyoacán, CDMX, C.P. 04510, México.

*Author for correspondence: ginny@unam.mx

(Received: January 2021; accepted: May 2021)

Key words: As bioaccessibility, $\mathrm{Pb}$ bioaccessibility, novel bioaccessibility equipment, NOM-147 method, in vivo-in vitro comparison, in vitro bioavailability.

\begin{abstract}
Contaminated soils can become exposure routes of elements toxic to human beings. The health risk of a toxic element by ingestion depends on its bioavailability in the gastrointestinal system, measured in vivo or in vitro. This study aimed to use a novel, versatile reactor (gastrointestinal simulation reactor system to determine bioaccessibility -GSRSB-) to measure lead and arsenic bioaccessibility in the gastric and intestinal phases by applying a modified physiologically based extraction test (PBET). Three composite samples of polluted soils with $\mathrm{As}(0.50-3.25 \%)$ and $\mathrm{Pb}(0.02-0.10 \%)$ and the certified reference material NIST 2710 were analyzed with this GSRSB-PBET method and the NOM-147 Mexican standard method, which uses an end-over-end shaker. All results were compared to one another. The NIST 2710 results were contrasted with those reported in vivo and in vitro by 14 laboratories. The (GSRSB-PBET) gastric phase ranges were 35.9-55.1\%(As) and 59.6-96.1\% (Pb), while (NOM-147) gastric phases were 35.8-60.4\% (As) and 61.0-70.7 \% (Pb). The (GSRSB-PBET) intestinal phase ranges were 39.5-46.9 \% (As) and 19.9-31.5\% $(\mathrm{Pb})$. The $\mathrm{As}$ and $\mathrm{Pb}$ compounds and the stirring technique seem to influence bioaccessibility. On the other hand, the comparison of NIST 2710 results with those reported in vitro and in vivo indicated that $\mathrm{As}$ and $\mathrm{Pb}$ gastric bioaccessibility obtained with GSRSB-PBET falls into the in vivo results range, while NOM-147 results are higher and fall outside the in vivo range, possibly overestimating the risk. Thus, the proposed method is adequate for modifying the current Mexican Standard Method (NOM-147), which only allows the calculation of $\mathrm{Pb}$ gastric bioavailability in vitro.
\end{abstract}

Palabras clave: bioaccesibilidad de As, bioaccesibilidad de $\mathrm{Pb}$, equipo novedoso de bioaccesibilidad, método NOM-147, comparación in vivo-in vitro, biodisponibilidad in vitro. 


\section{RESUMEN}

Los suelos contaminados pueden ser fuentes de exposición de elementos tóxicos para los seres humanos. El riesgo a la salud de un elemento tóxico por ingestión depende de su biodisponibilidad gastrointestinal, medida in vivo o in vitro. El objetivo de este estudio fue evaluar un reactor novedoso y versátil (GSRSB) para medir la bioaccesibilidad de plomo y arsénico en las fases gástrica e intestinal aplicando un método de extracción de base fisiológica (PBET, por sus siglas en inglés) modificado. Se analizaron tres muestras compuestas de suelos contaminados con As $(0.50-3.25 \%)$ y $\mathrm{Pb}(0.02-0.10 \%)$ y el material de referencia certificado NIST 2710 usando el método GSRSB-PBET y el método estándar mexicano NOM-147, utilizando un agitador axial. Los resultados del NIST 2710 se contrastaron con los informados in vivo e in vitro por 14 laboratorios. Los resultados en la fase gástrica (GSRSB-PBET) fueron 35.9-55.1\% (As) y 59.6-96.1\% (Pb), en fase intestinal (GSRSB-PBET) 39.5-46.9\% (As) y 19.9-31.5\% (Pb); mientras que la fase gástrica (NOM-147) fueron 35.8-60.4\% (As) y 61.0-70.7\% (Pb). Los compuestos de As y $\mathrm{Pb}$ y la técnica de agitación parecen influir en la bioaccesibilidad. La comparación de los resultados del NIST 2710 con los reportados in vitro e in vivo indicó que la bioaccesibilidad gástrica de $\mathrm{As}$ y $\mathrm{Pb}$ obtenida con GSRSB-PBET está en el intervalo de los resultados in vivo, mientras que los resultados obtenidos con la NOM-147 son mayores y fuera del intervalo in vivo, posiblemente sobrestimando el riesgo. El método propuesto es adecuado para modificar el actual método estándar mexicano (NOM-147) que sólo determina la biodisponibilidad gástrica del $\mathrm{Pb}$ in vitro.

\section{INTRODUCTION}

The primary anthropogenic activities responsible for higher levels of potentially toxic elements (PTE) in the environment are energy production and miningmetallurgy (Panayotova 2016, Sposito 2008, Masindi and Muedi 2018). The biogeochemical cycles of several elements, including arsenic (As) and lead (Pb), have been disturbed (Masindi and Muedi 2018), and populations can be exposed to polluted soil and water. Depending on the dose and chemical species, As and $\mathrm{Pb}$ ingested may harm human health (Kumpiene et al. 2017). Other factors influence toxicity, mainly the route of exposure, solubility, particle size, environmental matrix type, and the presence of certain substances that reduce or improve their absorption. The $\mathrm{Pb}$ acetate is one of the most bioavailable compounds because it is very soluble (Freeman et al. 1994) but most of the $\mathrm{Pb}$ in soils is forming compounds with low solubility (Rooney 2002). In the gastrointestinal tract, iron, zinc, and calcium decrease $\mathrm{Pb}$ absorption, possibly competing for absorption receptors in the intestine. Biogeochemical transformations control As bioavailability, toxicity, and its environmental fate. As can be oxidated by diverse compounds or reduced by organic compounds, forming more toxic inorganic species. Direct reduction of Fe (III) by microorganisms can lead to As sequestration by sorption (Borch et al. 2010). These processes have a big influence on the As bioavailability in vivo and, consequently, on in vitro determinations.

Several toxic arsenic species may form in the intestine because of the reaction between arsenic and food compounds. (Conrad and Barton 1978, Mushak 1991, Diamond et al. 1998, Calatayud and Llopis 2015, Ollson et al. 2017)

The damages caused by arsenic are classified as carcinogenic, mutagenic, or genotoxic, producing immunological, reproductive, developmental, neurological, renal, hepatic, hematological, gastrointestinal, cardiovascular, pulmonary, respiratory, and dermal harm (Mandal and Suzuki 2002, Sattar et al. 2016). $\mathrm{Pb}$ is classified as "probably carcinogenic to humans" (Group 2A), according to IARC (2006). It has mainly neurocognitive and behavioral effects (Chiodo et al. 2004, Mason et al. 2014) and decreases children's intellectual quotient (Schnaas et al. 2006, Mitra et al. 2017). However, because of various factors, most above mentioned, only part of the ingested element is absorbed through the gastrointestinal tract. This absorbed fraction is named bioavailable (Zhu et al. 2015). It can be measured as an absolute amount or a relative amount (Ruby et al. 1996, 1999, Juhasz et al. 2009, USEPA 2012, Koch et al. 2013).

Bioavailability is determined using animal models (in vivo), which is expensive, time-consuming (days or months), and raises ethical considerations. As an alternative to bioavailability tests, bioaccessibility 
tests mimic the human gastrointestinal processes (in vitro) being less costly and faster; these are also named in vitro bioavailability methods (Ruby et al. 1999, Juhasz et al. 2014, Liu et al. 2017).

Regulatory frameworks related to the remediation of polluted soils follow a risk assessment approach, and bioaccessibility is an adjustment factor in the calculations (USAEC, 2003). Mexican environmental regulation NOM-147-SEMARNAT/SSA12004 follows the same approach. Nevertheless, this regulation only allows the calculation of soil cleanup target levels based on gastric bioaccessibility of $\mathrm{Pb}$ measured through the simple bioaccessibility extraction test (SBET) (Dabin et al. 2012, Koch et al. 2013) using an end-over-end shaker.

In the Environmental Biogeochemistry Laboratory of the School of Chemistry of the National Autonomous University of Mexico (UNAM), PTE bioaccessibility is measured frequently. A novel agitation system called gastrointestinal simulation reactor system to determine bioaccessibility (GSRSB) was designed and built to facilitate this determination. It allows continuous control of the $\mathrm{pH}$ and improves gas flow stability, simplifying the reagents' addition and aliquots sampling during phase change. Characteristics of the vessels of the agitation equipment avoids sedimentation and soil erosion (Quiroz-Vivanco 2018). This study aimed to use the GSRSB with the physiologically based extraction test (PBET) to measure $\mathrm{Pb}$ and As gastric and intestinal bioaccessibility in polluted soils, to show the performance of this novel equipment, and to have data to propose this method (GSRSB-PBET) as an alternative to the current NOM-147 standard method. As and Pb bioaccessibilities of three composite soil samples and the certified reference material from the National Institute of Standards and Technology (NIST) Montana High number 2710 (NIST 2710) were measured by GSRSB-PBET and NOM-147 methods to reach this goal, both methods results were compared. Additionally, only NIST 2710 results were compared with those reported in vivo and in vitro by 14 laboratories, applying 17 methods (Koch et al. 2013).

\section{METHODS AND MATERIALS}

\section{Sampling}

The soil samples were collected at a site in Central Mexico, where $\mathrm{Pb}$ and $\mathrm{Cu}$ smelters and an $\mathrm{As}_{2} \mathrm{O}_{3}$ production facility were operating for more than 90 years (Gutiérrez-Ruiz et al. 2003, Villalobos 2010, Martínez-Jardines 2018). The area has a BSk climate according to the Köppen-Geiger classification, with an annual temperature of $16.8^{\circ} \mathrm{C}$ and an annual rainfall of $341 \mathrm{~mm}$ (CLIMATE-DATA, 2021). The soils are acidic (Martínez-Jardines 2018). According to Gutiérrez-Ruiz (2003) and Martínez-Jardines (2018), the soils were polluted with slag containing $\mathrm{Si}, \mathrm{Fe}, \mathrm{Ca}, \mathrm{K}, \mathrm{Pb}, \mathrm{Cu}$ and much lower quantities of $\mathrm{Mn}, \mathrm{As}, \mathrm{Ni}, \mathrm{Ba}$ and $\mathrm{Cd}$, mainly as oxides but also as sulfides. Other important wastes that polluted the site and were characterized are converter flue dust, smelting furnace flue dust, calcine, and black arsenic.

\section{Sample preparation}

The polluted site was in a remediation process, and from the complete set of soil samples collected $(\mathrm{N}=800)$, nine were selected based on their arsenic content, using a non-probability judgment sampling method (Frey 2018). The coordinates of the sites chosen are presented in table I. The nine samples (S1-S9) and wastes (converter flue dust, smelting furnaces flue dust, calcine, and black arsenic) were dried $\left(40{ }^{\circ} \mathrm{C}\right)$, ground, sieved (mesh $\# 10<2 \mathrm{~mm}$ ), and homogenized by quartering (Hesse 1971). Portions of $100 \mathrm{~g}$ were re-milled (ball grinder Fritsch), sieved (mesh \#200<74 $\mu \mathrm{m}$ ) (same particle size of NIST 2710 certified material) and preserved at room temperature $\left(15-20^{\circ} \mathrm{C}\right)$ in hermetically sealed plastic containers. The three composite samples were prepared $(\mathrm{C} 1, \mathrm{C} 2$, and $\mathrm{C} 3)$, mixing $100 \mathrm{~g}$ of three individual soils (Table I) selected by geographic proximity and As concentration: $\mathrm{C} 1$ (S1, S2, S3); C2 (S4, S5, S6) and C3 (S7, S8, S9).

\section{Analytical determinations}

All chemicals used were analytical reagent grade (AR grade). Deionized water was used to prepare all solutions for the leaching tests and all analytical procedures. All determinations were done in triplicate, and their relative standard deviations (RSD) calculated (values in tables). All the extracts were preserved in the dark at $4{ }^{\circ} \mathrm{C}$. Elements were quantified using ICP-OES (Agilent Technologies model 5100), applying method 6010C (USEPA 2000). Digestions were done using an Ethos Easy microwave digestion system (Millestone Inc.) using Teflon PFA beakers applying US-EPA method 3051A (USEPA 2007b).

\section{General composition and geoavailability}

The $\mathrm{pH}$ in soils and wastes was measured following ISO-10390:2005 with a model Orion Star A211 Thermo Scientific potentiometer. Total concentrations of $\mathrm{As}, \mathrm{Pb}, \mathrm{Fe}, \mathrm{Ca}, \mathrm{Cd}, \mathrm{Cu}, \mathrm{Zn}$, and $\mathrm{Mn}$ were measured with a portable model DP-6000-CC 


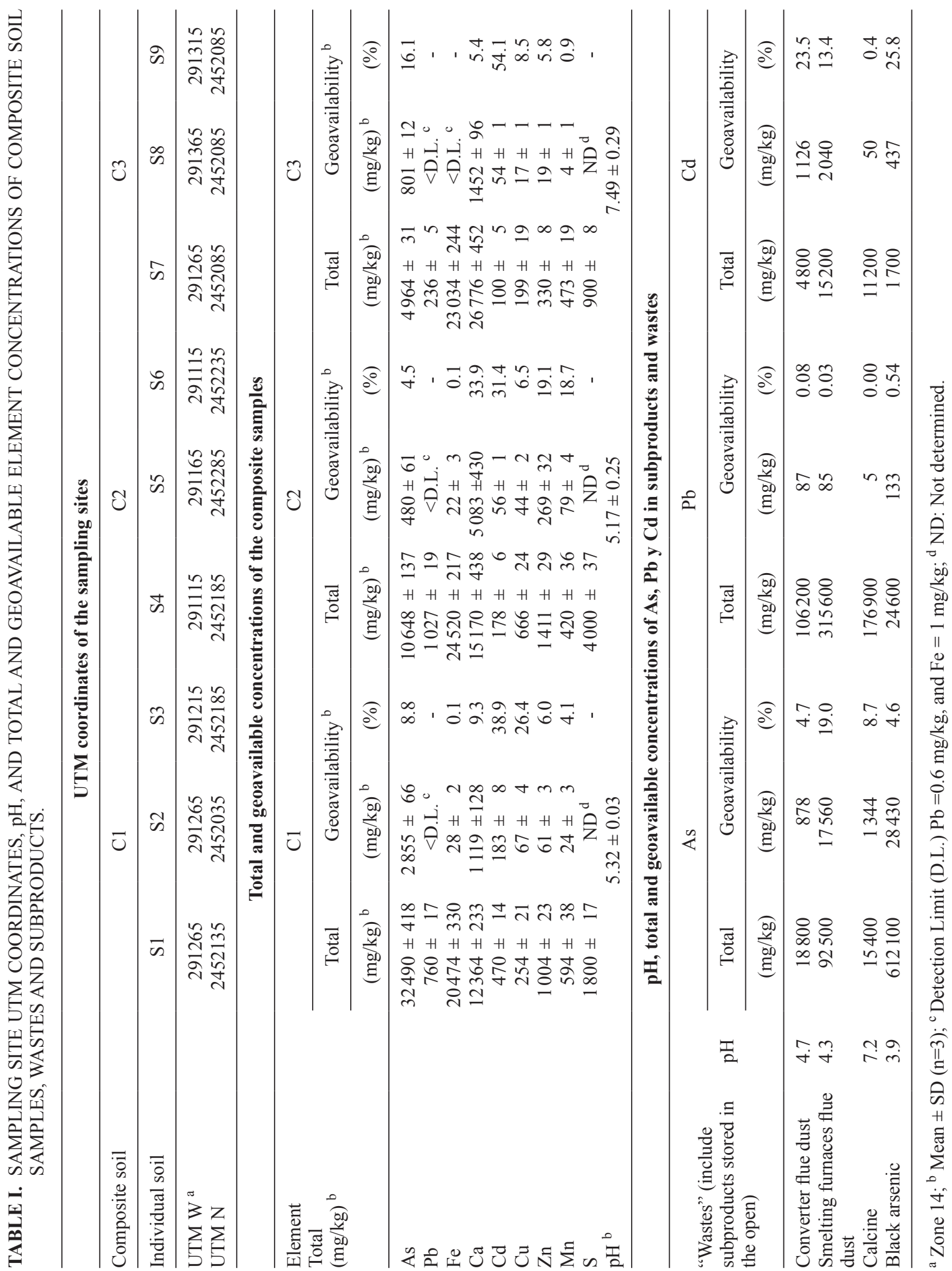


Thermo Scientific X-ray fluorescence Olympus analyzer using the 6200 method (USEPA 2007, ZamoraMartínez et al. 2008). Total sulfur was determined in a model S-832 Leco analyzer (Bremner and Tabatabai 1971). All composite soils were analyzed by SEMEDS in a Hitachi TM1000 tabletop scanning electron microscope with an energy dispersive spectroscopy module, and by X-ray diffraction (XRD) with a Shimadzu XRD-6000 equipped with a $\mathrm{Cu}$ tube and a graphite monochromator. Blanks and certified reference materials were used for quality control for individual and composite soil analysis: pH (NISTtraceable buffer solutions), XRF (NIST 2711a), sulfur content (Oreas 45b) and ICP-OES determinations (HPS, QCS-26). Geoavailable concentrations in soils and wastes were determined with the D3987-06 method (ASTM 2006).

\section{Soils bioaccessibility}

Two methods have been used to measure the bioaccessibility of soils: NOM-147, which only includes the gastric phase and was applied as indicated by Mexican regulation (SEMARNAT 2007) using glycine at $\mathrm{pH}=1.50 \pm 0.05(\mathrm{HCl})$ and an end-over-end shaker $\left(37 \pm 2{ }^{\circ} \mathrm{C}\right)$. This method is analogous to the SBET, RBALP and SBRC (Dabin et al. 2012). The other method used was the PBET (Ruby et al. 1996), which determines gastric and intestinal phases. The reagents used include pepsin, citrate, malate, lactic acid, and acetic acid in the gastric phase and bile salts and pancreatin in the intestinal phase. Reagent quantities, ratios (solid/liquid), and residence times were applied as indicated by Ruby et al. (1996). A modification was made in the gastric phase, adjusting the $\mathrm{pH}$ to $1.50 \pm 0.05$ with $\mathrm{HCl}(11 \mathrm{M})$ as was reported to increased in vitro and in vivo correlations (Drexler and Brattin 2007, Juhasz et al. 2014). After the gastric phase concluded, $\mathrm{pH}$ was gradually increased to $7.00 \pm 0.10$ with a $\mathrm{NaHCO}_{3}$ saturated solution and subsequently, pancreatin and bile salts were added.

Intestinal extracts were digested $\left(\mathrm{HNO}_{3}\right.$-microwave-assisted, method 3051A) (USEPA 2007b) using an Ethos Easy (Milestone) to destroy organic compounds that interfere with PTE quantification by ICP-OES (USEPA 2000). Argon was used as a stirring gas in the novel reactor (GSRSB). As mentioned above, it was exclusively designed in our laboratory. It is used to improve the control $\mathrm{pH}$ and gas flow stability, simplifying the reagents' addition and taking of aliquots during the phase change. It has conical bottom glass reactors placed in a heating bath $\left(37 \pm 1^{\circ} \mathrm{C}\right)$. The vessels contain a thin tube through which the argon enters and stirs the suspension $(1 \mathrm{~L} / \mathrm{min})$ (Fig. 1). The conical design is used to prevent the sedimentation and erosion of soil particles. The $\mathrm{pH}$ electrodes are placed inside each reactor, allowing measurements without stopping the agitation process. A small orifice is used to take aliquots or add reagents during the gastric-to-intestinal phase change and to introduce pH electrodes (García-Rodríguez 2017, Quiroz-Vivanco 2018). The NOM-147 end-overend shaker (Fig. 1) controls the temperature with an immersion recirculation heater. Nevertheless, it does not allow one to measure $\mathrm{pH}$, take aliquots, or add reagents when the shaker is in motion.

In this study, the absolute bioaccessibility was calculated as the ratio between the element concentration $(\mathrm{mg} / \mathrm{kg})$ in the solution for each method or extraction phase, respect to the element concentration in the soil $(\mathrm{mg} / \mathrm{kg})$ in percentage. To calculate the relative bioaccessibility, the bioaccessibility results were corrected with the mean of three spike results

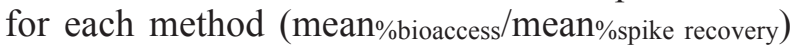
according to Koch et al. (2013).

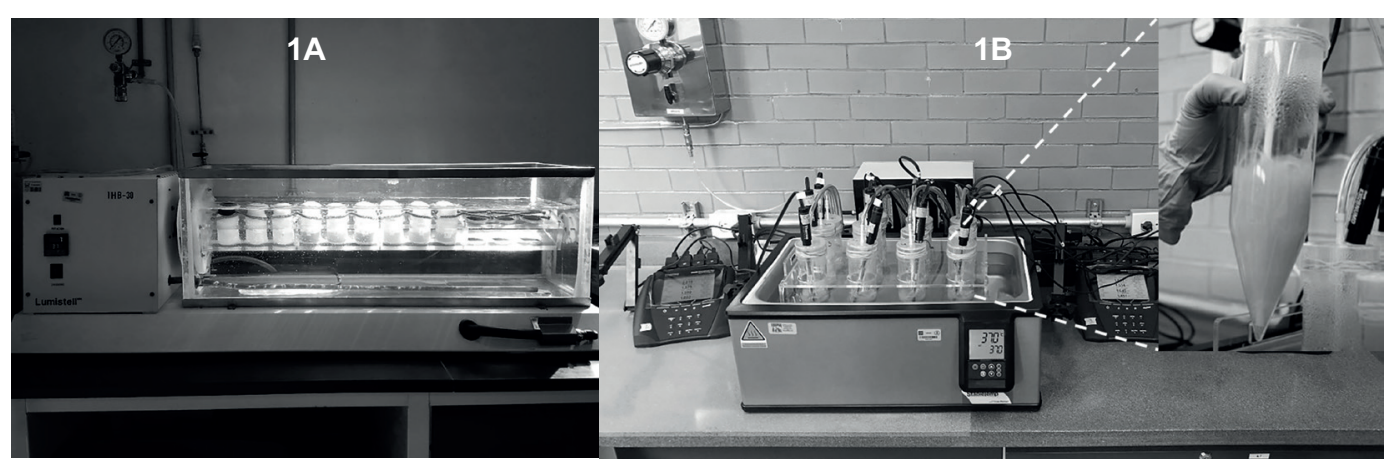

Fig. 1. Equipment used to measure oral bioaccessibility: (1A) End-over-end shaker NOM-147 method (gastric phase) and (1B) GSRSB-PBET method (gastric and intestinal phases). 


\section{RESULTS}

\section{General composition and geoavailability}

The $\mathrm{pH}$, total element concentration and geoavailability (soluble fraction in meteoric water at $\mathrm{pH}=5.5$ \pm 0.3 ) of $\mathrm{As}, \mathrm{Pb}, \mathrm{Fe}, \mathrm{Ca}, \mathrm{Cd}, \mathrm{Cu}, \mathrm{Zn}$ and $\mathrm{Mn}$ were quantified in individual samples (data not shown) and in composite samples (Table I). In the nine individual soils, the range of $\mathrm{pH}$ was 3.7-8.0, while in groups $\mathrm{S} 1, \mathrm{~S} 2, \mathrm{~S} 3=4.73-6.10, \mathrm{~S} 4, \mathrm{~S} 5, \mathrm{~S} 6=3.7-5.16$ and $\mathrm{S} 7$, $\mathrm{S} 8, \mathrm{~S} 9=7.8-8.0$. The range of total As for $\mathrm{S} 1-\mathrm{S} 9=$ $0.43-4.15 \%$, for S1, S2, S3 = 2.05-4.15\%, for S4, S5, $\mathrm{S} 6=0.62-1.59 \%$ and for S7, S8, S9 $=0.43-0.49 \%$. The range of total $\mathrm{Pb}$ for $\mathrm{S} 1-\mathrm{S} 9=0.02-0.16 \%$, for $\mathrm{S} 1$, $\mathrm{S} 2, \mathrm{~S} 3=0.04-0.16$, for S4, S5, S6 $=0.02-0.14$ and for $\mathrm{S} 7, \mathrm{~S} 8, \mathrm{~S} 9=0.02-0.03 \%$.

The formation of hydrolysable sulfates from the oxidation of sulfide could explain the acidity of most of the samples (Ward et al. 2004, Romero et al. 2008). Samples S7 to S9 had a weak positive reaction to acid due carbonates, explaining their basic $\mathrm{pH}$. The As geoavailability of S1-S9 $=418-2048(\mathrm{mg} / \mathrm{kg})$, $\mathrm{S} 1, \mathrm{~S} 2, \mathrm{~S} 3=1381-2048(\mathrm{mg} / \mathrm{kg}), \mathrm{S} 4, \mathrm{~S} 5, \mathrm{~S} 6$ $=418-920(\mathrm{mg} / \mathrm{kg})$, and $\mathrm{S} 7, \mathrm{~S} 8, \mathrm{~S} 9=682-$ 1017 (mg/kg) (García-Rodríguez 2017). Pb geoavailability was lower than the detection limit $(\mathrm{DL}=0.6 \mathrm{mg} / \mathrm{kg})$. Total and geoavailable As are correlated $(\mathrm{r}=0.95)$, but not with the $\mathrm{pH}$ (As total vs $\mathrm{pH}(\mathrm{r}=-0.62)$ and As geoavailable vs $\mathrm{pH}(\mathrm{r}=-0.33))$. The total As range in wastes is 1.5-61.2\%, and geoavailable As varied from 878 to $28430(\mathrm{mg} / \mathrm{kg})$. The full $\mathrm{Pb}$ range in wastes is 2.5-31.5\%, and geoavailable $\mathrm{Pb}$ varied from 5 to $133(\mathrm{mg} / \mathrm{kg})$ (Table I). Total Fe concentrations in all composite samples are similar and high (Table I). Total concentrations varied for the other elements present. Sample C1 has the highest total $\mathrm{As}, \mathrm{Cd}$ and $\mathrm{Mn} . \mathrm{C} 2$ has the highest concentrations of $\mathrm{Pb}, \mathrm{Fe}, \mathrm{Cu}, \mathrm{Zn}$ and $\mathrm{S}$, while $\mathrm{C} 3$ has the lowest of those metals except for $\mathrm{Ca}$, which has the highest value (Table I).

The composite samples were analyzed through XRay Diffraction (XRD). The crystalline compounds identified were quartz, plagioclase, and $\mathrm{As}_{2} \mathrm{O}_{3}$. Weak signals were observed for augite $(\mathrm{Ca}, \mathrm{Na})(\mathrm{Mg}, \mathrm{Fe}$, $\mathrm{Al}, \mathrm{Ti})(\mathrm{Si}, \mathrm{Al})_{2} \mathrm{O}_{6}$, pharmacolite $\mathrm{CaH}\left(\mathrm{AsO}_{4}\right) \cdot 2 \mathrm{H}_{2} \mathrm{O}$, clinomimetite $\mathrm{Pb}_{5}\left(\mathrm{AsO}_{4}\right)_{3}$

$\mathrm{Cl}$, shultenite $\mathrm{PbHAsO}_{4}$, and anglesite $\mathrm{PbSO}_{4}$. Other compounds were expected because of previous findings in the soils of this area. $\mathrm{Cu}$ and $\mathrm{Zn}$ sulfates (Martínez-Jardines 2018) were not detected, probably due to low crystallinity or low concentration (Whitfield and Mitchell, 2008).
The SEM-EDS analysis of six particles from each of the composites (Fig. 2) showed analogous concentrations of the major elements ( $\mathrm{Al}, \mathrm{Si}$, and $\mathrm{Fe})$, whereas minor elements were variable.

The total concentrations of $\mathrm{Ca}$ and $\mathrm{Fe}$ were high, but with low geoavailability (Table I).

\section{Soils bioaccessibility}

All bioaccessibility data is presented in table II. The range of As bioaccessibility (\%) in the gastric phase (GSRSB-PBET) is 35.9-55.1\%, and for NIST 2710 is $46.3 \%$. The range of soil values using the NOM-147 method is higher $=35.8-60.4 \%$, and for NIST 2710 is $61.3 \%$. The percentage of As bioaccessibility in the intestinal phase by GSRSB-PBET is $39.5-46.9 \%$, and for NIST 2710 is $22.9 \%$. The $\mathrm{Pb}$ range in the gastric phase is 59.6-96.1\% from GSRSB-PBET, and the value for NIST 2710 is $72.0 \%$. The NOM-147 results range is $61.0-70.7 \%$, and for NIST 2710 is $90.8 \%$. In the intestinal phase, the range by GSRSB-PBET is $19.9-31.5 \%$, and for NIST is $36.6 \%$.

$\mathrm{Pb}, \mathrm{Cu}$ and $\mathrm{Zn}$ exhibit higher bioaccessibility than geoavailability (Tables I, II), showing that the solubility of these soil pollutants is low in meteoric water but increases under gastric conditions $(\mathrm{HCl}$, $\mathrm{pH}=1.5)$. The bioaccessibility of $\mathrm{Ca}, \mathrm{Cu}, \mathrm{Zn}$ and $\mathrm{Pb}$ increases with higher total concentration. Geoavailability is not related to bioaccessibility, except for As and $\mathrm{Zn}$ (gastric phase, NOM-147, Table II). The bioaccessibility values of $\mathrm{As}, \mathrm{Pb} \mathrm{Ca}, \mathrm{Cu}$, and $\mathrm{Zn}$ in the gastric phase (Table II) are higher than their geoavailability.

The bioaccessibility of $\mathrm{Pb}$ measured during the intestinal phase (PBET) is always lower than in the gastric phase using both methods. Nevertheless, As behavior is the opposite except in C3, the only basic sample.

One-way ANOVA tests for As and Pb bioaccessibilities in the gastric phase among both methods (NOM-147 and GSRSB-PBET) were applied to compare whether the samples means were significantly different or not (using the $\mathrm{F}$ distribution).

For As we concluded that both gastric methods are statistically different, comparing bioaccessibilities for samples $\mathrm{C} 1-\mathrm{C}-3$ ( $\mathrm{F}_{\text {calculated }} 4.71>\mathrm{F}_{\text {critical }}$ 3.89, two-way ANOVA), and for reference material NIST $2710\left(\mathrm{~F}_{\text {calculated }} 45.08>\mathrm{F}_{\text {critical }} 7.71\right.$, one way ANOVA). For $\mathrm{Pb}$ we also concluded that methods are statistically different, evaluating ANOVA for samples C1-C-3 ( $F_{\text {calculated }} 26.36>\mathrm{F}_{\text {critical }} 3.89$, twoway ANOVA), and NIST 2710 ( $\mathrm{F}_{\text {calculated }} 34.88>$ $\mathrm{F}_{\text {critical }} 7.71,1$ factor ANOVA. All tests were done at $95 \%$ of confidence. 

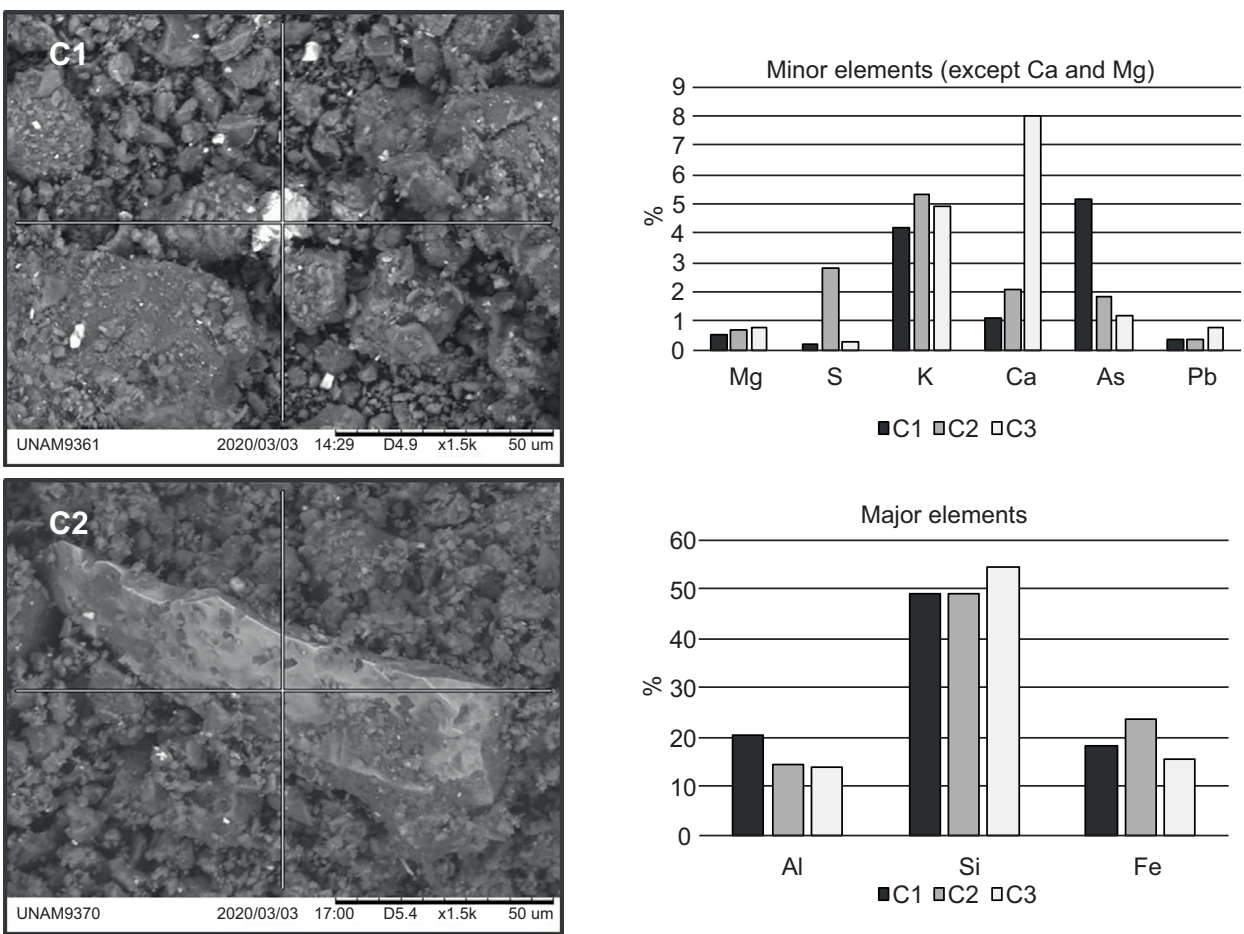

\begin{tabular}{|c|c|c|c|c|c|c|c|c|c|}
\hline \multirow{2}{*}{$\begin{array}{c}\text { Composite } \\
\text { samples }\end{array}$} & \multicolumn{10}{c|}{ \% w/w (average of 6 particles) } \\
\cline { 2 - 11 } & $\mathrm{Al}$ & $\mathrm{Si}$ & $\mathrm{Fe}$ & $\mathrm{Mg}$ & $\mathrm{S}$ & $\mathrm{K}$ & $\mathrm{Ca}$ & $\mathrm{As}$ & $\mathrm{Pb}$ \\
\hline $\mathrm{C} 1$ & 20.6 & 49.3 & 18.4 & 0.5 & 0.2 & 4.2 & 1.1 & 5.2 & 0.4 \\
\hline $\mathrm{C} 2$ & 14.3 & 49.3 & 23.5 & 0.7 & 2.8 & 5.3 & 2.1 & 1.8 & 0.4 \\
\hline $\mathrm{C} 3$ & 13.8 & 54.5 & 15.7 & 0.8 & 0.3 & 4.9 & 8.0 & 1.2 & 0.8 \\
\hline
\end{tabular}

Fig. 2. Average composition of particles of the composites. $\mathrm{C} 1$ and $\mathrm{C} 2$ micrographs are shown.

\section{Comparison between NIST 2710 bioaccessibility data and the in vitro and in vivo values reported by Koch et al. (2013)}

The magnitude of the $\mathrm{As}$ and $\mathrm{Pb}$ gastric bioaccessibility percentages of NIST 2710 calculated through the GSRSB-PBET method fall into the range for in vitro and in vivo results for the same standard (Table III and Fig. 3). It is important to mention that the result obtained is like those reported for in vitro by Koch et al. (2013) for the analogous method RMC-PBET. For the comparison of NIST 2710 results, we carried out statistical tests (one-way ANOVA) for As and $\mathrm{Pb}$ bioaccessibilities among the gastric phase (GSRSB-PBET method) and in vivo data reported (swine). We obtained that for As $\mathrm{F}_{\text {calculated }} 2.07<$ $\mathrm{F}_{\text {critical }}$ 7.71, and for $\mathrm{Pb} \mathrm{F}$ calculated $4.14<\mathrm{F}_{\text {critical }}$ 7.71, concluding that there is no significant statistically difference between GSRSB-PBET method and in vivo swine results.

The values obtained with the NOM-147 method are higher than the others and fall out of the in vivo range (Table III and Fig. 3). The in vitro mean value reported by Koch et al. (2013) is $59 \%$ for $\mathrm{Pb}$. A higher $\mathrm{Pb}$ bioaccessibility percentage in the gastric phase was obtained using the NOM-147 method ( 90.8 $\%), \mathrm{Pb}$ value measured with the RBALP method by Koch et al. (2013), it is the same as the NOM-147 method. We carried out statistical tests (one-way ANOVA) for both elements between the gastric phase (NOM-147 method) with swine As: $F_{\text {calculated }} 20.47$ $>\mathrm{F}_{\text {critical }}$ 7.71, and $\mathrm{Pb}: \mathrm{F}_{\text {calculated }}$ 17.87 $>\mathrm{F}_{\text {critical }}$ 7.71, and for As with mice $\mathrm{F}_{\text {calculated }} 95.20>\mathrm{F}_{\text {critical }}$ 7.71, concluding that NOM-147 method is statistically different with respect to in vivo results.

$\mathrm{The} \mathrm{Pb}$ bioaccessibility percentage in the intestinal phase (GSRSB-PBET) was $45.8 \%$. It is lower than the swine range values (73-79\%) (Table III, Fig. 3). Statistical one way ANOVA tests for both elements between the intestinal phase (GSRSB-PBET method) with swine (As: $F_{\text {calculated }} 166.35>F_{\text {critical }}$ 7.71, $\left.\mathrm{Pb}: \mathrm{F}_{\text {calculated }} 289.24>\mathrm{F}_{\text {critical }} 7.71\right)$ and for As with mice $\left(\mathrm{F}_{\text {calculated }} 119.43>\mathrm{F}_{\text {critical }} 7.71\right)$, indicate that intestinal phases are statistical different for in vivo results. 


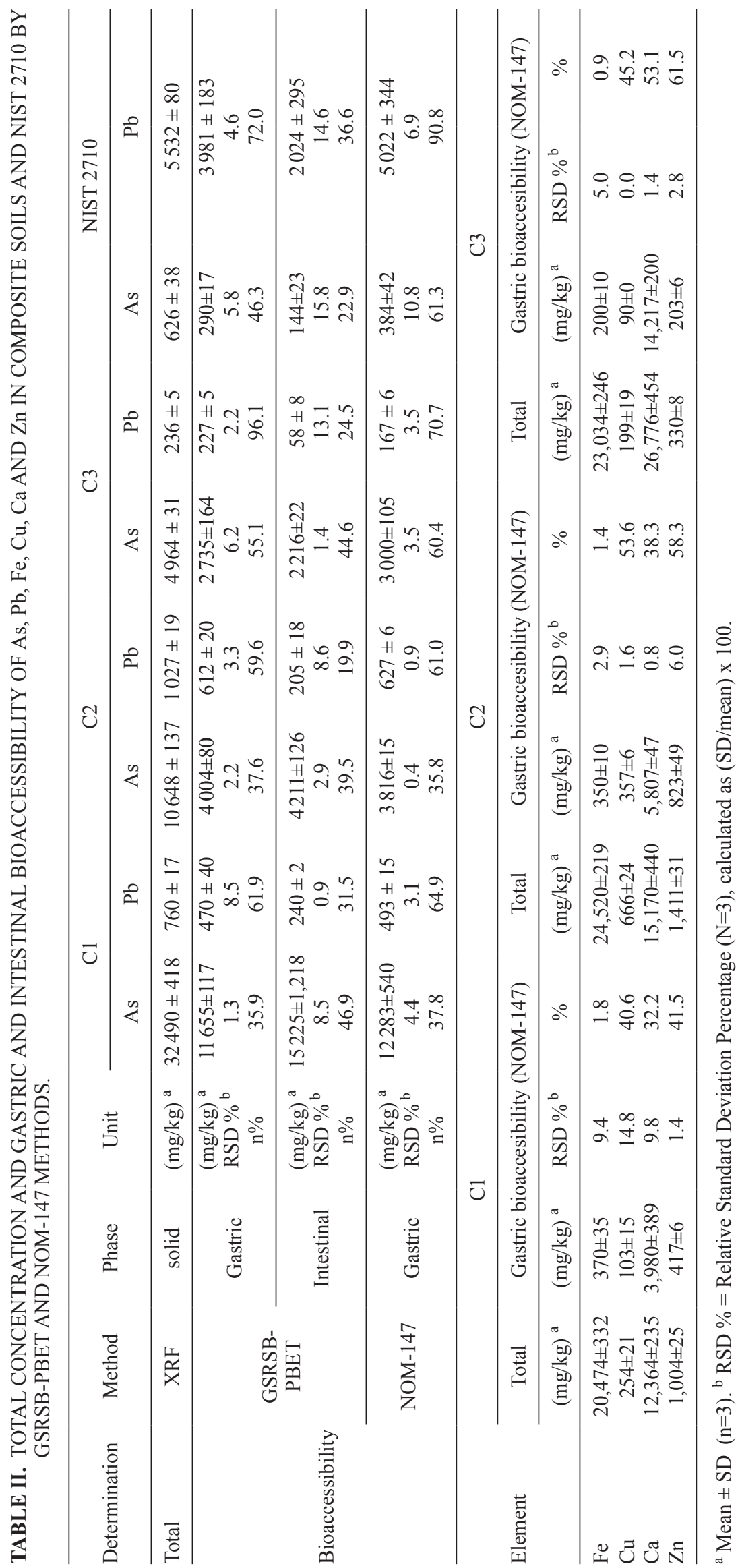




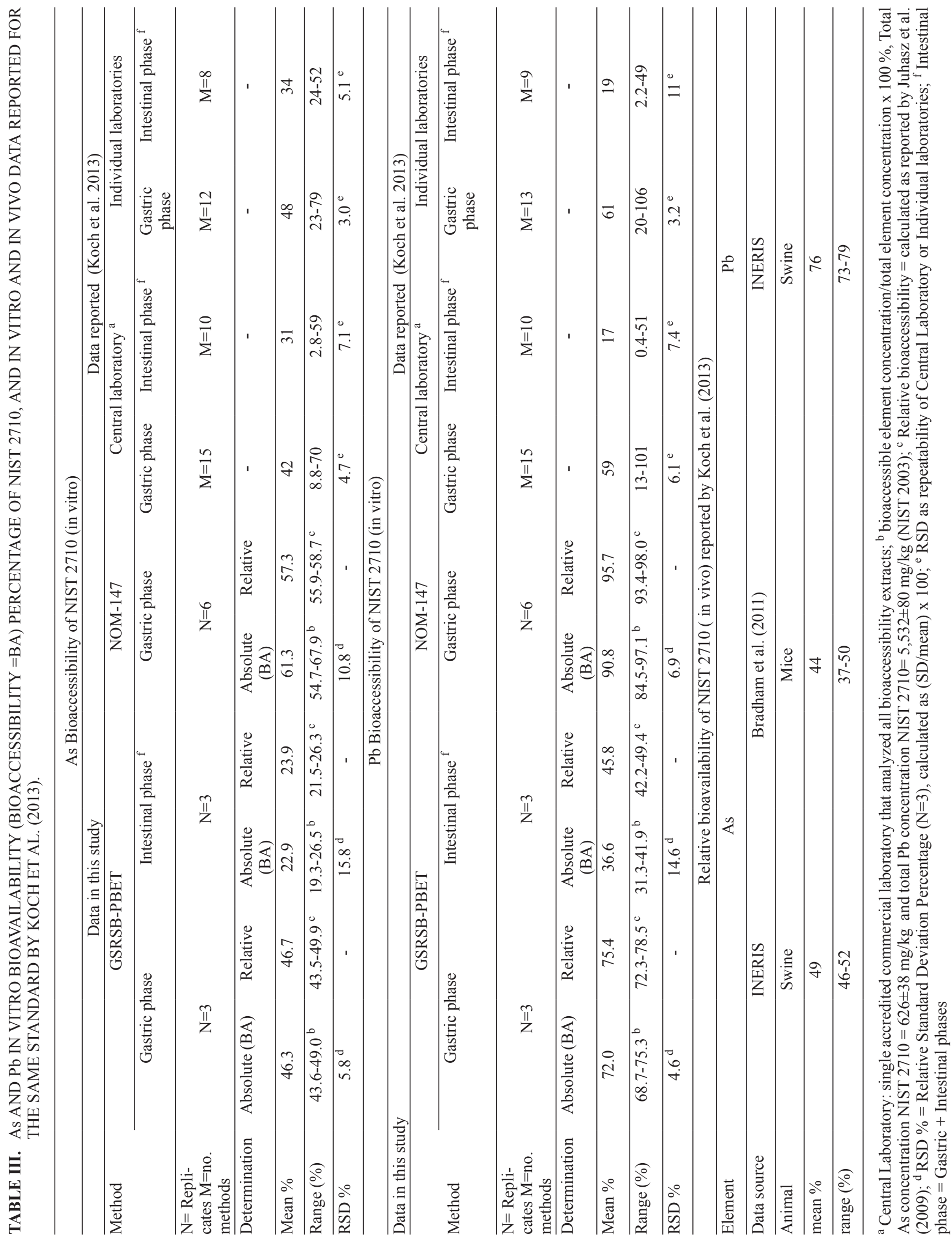




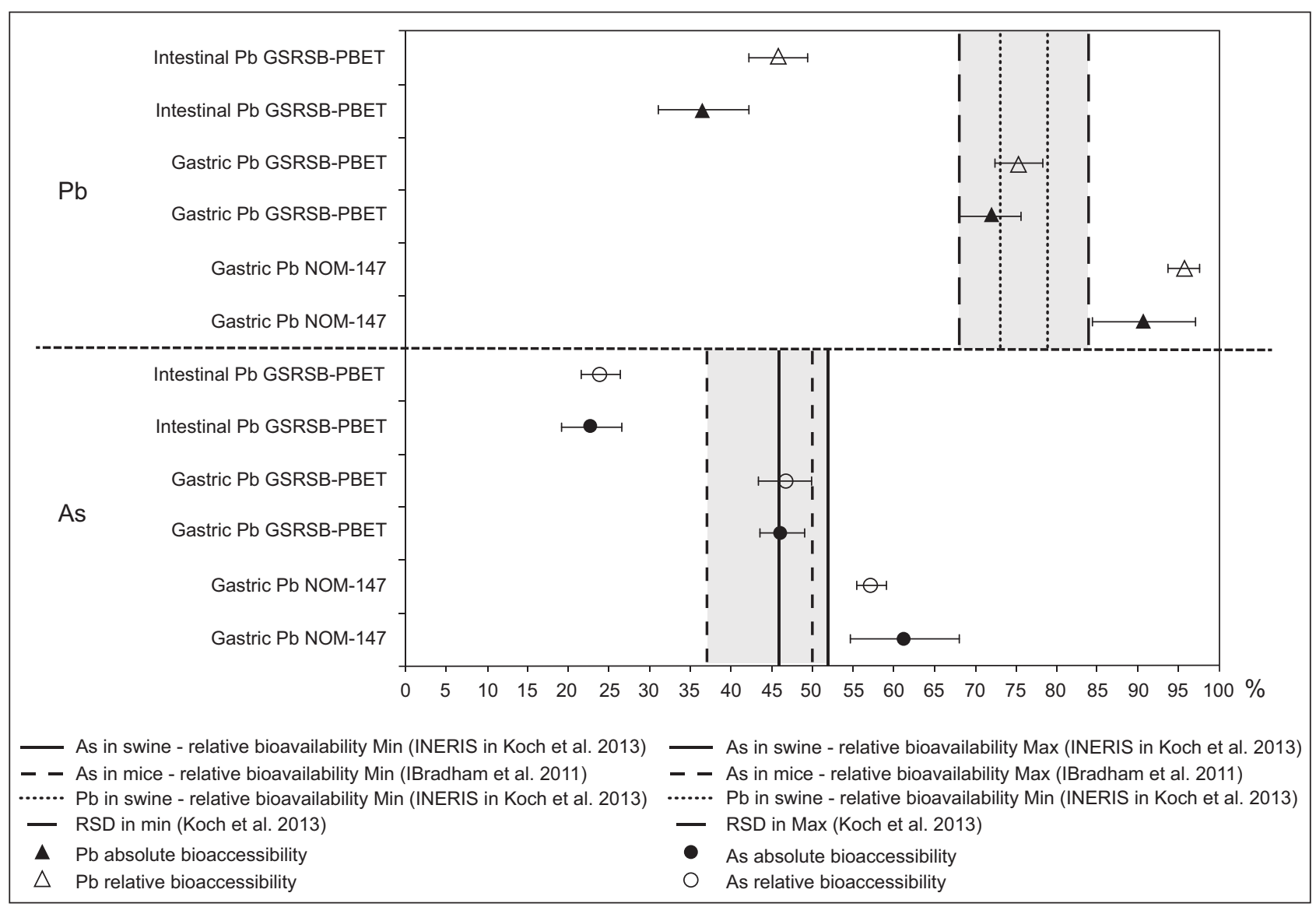

Fig. 3. As and $\mathrm{Pb}$ bioaccessibility results for the NIST 2710 and in vivo ranges reported by Koch et al. (2013). Note. The percentages of Relative bioavailability in swine (INERIS) and mice (Bradham et al. 2011) were taken from Koch et al. (2013). Relative bioaccessibility was calculated as reported by Juhasz et al. (2009). Intestinal phase $=($ gastric + intestinal $)$.

Indeed, statistical tests of the results obtained in vitro between $\mathrm{As}$ and $\mathrm{Pb}$ with those measured in vivo reported to the same standard by Koch et al. (2013), indicates that only the results of the gastric phase of GSRSB-PBET have not statistically differences with the in vivo results, and fall in the range as can be seen in figure 3. As and $\mathrm{Pb}$ bioaccessibilities measured in the NIST 2710 (gastric phase) are more precise (less dispersion of results, reported as \% Relative standard deviation) with the GSRSB-PBET method than the NOM-147 (Table III).

Absolute and relative percentages for both elements are similar (Table III) because there is no significant statistically difference evaluating by a one-way ANOVA. Absolute and relative percentages for both elements are similar (Table III) because there is no significant statistical difference evaluating a one-way ANOVA. The comparison results concerning a Fcritical $=7.71$ for As bioaccesibilities in vivo and the gastric phases from GSRSB-PBET, and NOM-147; and the intestinal phase GSRSBPBET method gave Fcalculated 0.03, 1.05, and 0.16, respectively. Also, $\mathrm{Pb}$ ANOVA comparisons for in vivo and the gastric phases from GSRSB-PBET method, NOM-147 method, and the intestinal phase for GSRSB-PBET gave Fcalculated 1.69, 1.60 6.19, respectively. In all cases concluding that results are not statistically different from in vivo results. All the statistical ANOVA tests were done with $95 \%$ confidence.

\section{DISCUSSION}

In general, the main elements $\mathrm{As}, \mathrm{Pb}, \mathrm{Fe}, \mathrm{Ca}, \mathrm{Cd}$, $\mathrm{Cu}, \mathrm{Zn}, \mathrm{Mn}$, and S (Table I) and the compounds 
identified by XRD in soils match with the composition reported by Gutiérrez-Ruiz et al. (2003), Romero et al. (2008), Villalobos et al. (2010) and Martínez-Jardines (2018), for the same site. Ca and $\mathrm{Pb}$ arsenates (phamacolite and clinomimetite) were identified. They are secondary minerals that slowly form in soils of semi-arid regions. Anglesite $\left(\mathrm{PbSO}_{4}\right)$, arsenolite $\left(\mathrm{As}_{2} \mathrm{O}_{3}\right)$, and clay with $\mathrm{Fe}, \mathrm{Ca}$, and $\mathrm{Mg}$ were also identified. $\mathrm{CaCO}_{3}$ was detected indirectly in $\mathrm{C} 3$ through the reaction of carbonates with $\mathrm{HCl}$. Nevertheless, other compounds reported in this terrain's soil samples were not identified, possibly due to low concentrations or crystallinity. Most compounds found in analyzed soils in the study site included traces of arsenopyrite (Pokrovski et al. 2002), $\mathrm{PbS}$, $\mathrm{CaSO}_{4} \cdot 2 \mathrm{H}_{2} \mathrm{O}$, goethite $(\mathrm{FeOOH})$, magnetite $\left(\mathrm{Fe}_{3} \mathrm{O}_{4}\right)$, chalcopyrite $\left(\mathrm{CuFeS}_{2}\right)$, and pyrite $\left(\mathrm{FeS}_{2}\right)$.

Furnace and converter dust and black arsenic must be the primary sources of $\mathrm{As}$ and $\mathrm{Pb}$ in the soil for two reasons: they are very rich in these elements, and calcine could contribute to $\mathrm{Pb}$ concentration (Table I). Overall, composites composition is similar to that of $\mathrm{Cu}$ slag (Nazer et al. 2016). The low geoavailability of $\mathrm{Ca}$ and $\mathrm{Fe}$ with high total concentration, possibly can be explained considering that these elements are in the slag. Moreover, variability of the total and geoavailable concentrations of minor elements (Table I and Fig. 2) shows a possible mixture of slag with converter flue dust, smelting furnace flue dust, sulfates, and carbonates. The diverse geoavailability of all elements except Fe (that was always low) can be attributed to the varied composition of the residues and byproducts that polluted the soil as converter flue dust, smelting furnace flue dust, calcine, and black arsenic (Table I). The $\mathrm{CaCO}_{3}$ in sample $\mathrm{C} 3$ explains the $\mathrm{pH}>7$. $\mathrm{Pb}, \mathrm{Cu}$, and $\mathrm{Zn}$ sulfates explain the $\mathrm{pH}<7$ of samples $\mathrm{C} 1$ and $\mathrm{C} 2$, as well as their low solubility in meteoric water (geoavailability) and high bioaccessibility in the gastric phase. These observations coincide with the data reported in other studies (Walraven et al. 2015, González-Grijalva et al. 2019). Despite this, not all of these metals must be sulfates. A portion of low concentrations may come from the acid lixiviation of slag in the gastric phase. $\mathrm{Ca}$ content in carbonate and plagioclase minerals could explain low geoavailability in meteoric water and high bioaccessibility under acidic conditions.

Arsenic geoavailability varies from 480 to 2855 $\mathrm{mg} / \mathrm{kg}$. Sample C3, with the lowest total As concentration and high geoavailability, emphasizes the great importance of the compound's behavior. The soils contain As (III) in addition to As (V) compounds, which have been identified in this and other studies
(Martínez-Jardines 2018). They can coexist because of dry weather conditions on site, and because reduction from arsenate to arsenite is slow (ATSDR 2007). The geoavailable As fraction must be mainly related with arsenolite, since the As (V) compounds have limited solubility in meteoric water. Although a number of arsenates could be adsorbed in amorphous Fe compounds (Goldber 2002, Donahoe et al. 2005, Hernández et al. 2016), it is not likely in this case. Fe in these soils seems to mainly be in the slag, because the geoavailable and bioaccessible fractions are quite low (Tables I, II). Furthermore, supposing the existence of amorphous oxides, Fe should be released during gastric extraction by chelation with organic ligands (Sidhu et al. 1981). Nevertheless, gastric Fe bioaccessibility was very low.

$\mathrm{Pb}$ geoavailability at $\mathrm{pH}=5.5$ was negligible but not its bioaccessibility, suggesting that $\mathrm{Pb}$ is mainly identified in low water-soluble sulfates, arsenates, carbonates and slag, but not under acidic conditions. It could also be identified in sulfides (González-Grijalva et al. 2019). All the compounds reported above can be partially solubilized under the acid condition of the gastric phase, even the slag (Aoki et al. 1984). $\mathrm{Pb}$ adsorption in birnessite or other Mn oxides that cover clays should be considered, since Mn compounds present hydroxyl groups favoring adsorption (Yin et al. 2011) at $\mathrm{pH}=4.5-5.5$ (Lenoble et al. 2002), although it is unlikely under gastric conditions. GonzálezGrijalva et al. (2019) reported a $\mathrm{Pb}$ range from 40.8 to $50.8 \%$, lower than those obtained in this study. Considering that particle homogenization, temperature, and extraction times were the same, a possible factor related to data variability and soil composition could be the agitation system. The end-over-end shaker used in the NOM-147 method causes particle collision, reduction in particle size, and can increase soil reactivity (Quiroz-Vivanco 2018). The GSRSB uses a gas system that avoids biases in the expected results related to mechanical agitation. However, evidence of agitation's influence is limited due to the insufficient number of analyzed samples.

Indeed, compound characteristics seem to be the most relevant factor explaining the variability. Even As lixiviated from slag can form soluble compounds under gastric conditions, depending on each reaction's kinetics. Arsenic can exist as $\mathrm{H}_{3} \mathrm{AsO}_{3}$ and $\mathrm{H}_{3} \mathrm{AsO}_{4}$, or possibly as arsenates adsorbed in clays due to slow reduction. Clays do not dissolve in $\mathrm{HCl}$ (Simon and Anderson 1990), but can be partially altered, producing amorphous solids with a positive charge (Smedley and Kinniburg 2002). Acidic conditions increase the sorption capacity of clays, 
forming complexes with anions as arsenates at low pH (Simon and Anderson 1990, Magalhães 2002, Zhang and Selim 2005, Elsheikh et al. 2018). The soluble As (III) from arsenolite cannot be absorbed because the $\mathrm{H}_{3} \mathrm{AsO}_{3}$ is neutral and only acquires a negative charge at very high $\mathrm{pH}$ (Wang and Mulligan 2006).

$\mathrm{Pb}$ could be soluble or coordinated with organic ligands in the gastric solution. The NOM-147 method uses glycine, which forms $\mathrm{Pb}\left(\mathrm{NHCH}_{2} \mathrm{COOH}\right)_{2}$ (Zhang et al. 2011), a soluble compound that mobilizes $\mathrm{Pb}$ from bones (Alcaraz-Contreras et al. 2011). The PBET method uses citrates, acetates, and other organic chelates. All of these can form soluble compounds with metals, releasing arsenates (Ruby et al. 1993). For example, citrates are useful to recover $\mathrm{Pb}$ from batteries (Villa-Vargas 2017, Villa et al. 2018), and acetates leach $\mathrm{Pb}$ from calcines (García-Villa 2016).

The observed differences between gastric and intestinal bioaccessibility have been related to particle size, mineral solubility, sorption complexes, soil characteristics, and new compounds (Ruby et al. 1999, Walraven et al. 2015). In this case, in soils with acid $\mathrm{pH}$ and low $\mathrm{Ca}$ content, a higher As bioaccessibility in the intestinal phase than in the gastric phase was observed. One possible explanation is the adsorption of arsenates on clays under gastric conditions, being released in the intestinal phase when the $\mathrm{pH}$ increases to neutrality with $\mathrm{NaHCO}_{3}$ and the clays lose their charge. Although Singh et al. (2011) reported that some abiotic or biotic oxidoreduction reactions could happen with the added reagents changing the solubility of As, García-Rodríguez (2017) reported that adding only $\mathrm{Na}_{2} \mathrm{HCO}_{3}$ also recovered lower As in the gastric phase than in the intestinal, reinforcing our hypothesis.

$\mathrm{Pb}$ in the intestinal phase was lower than in the gastric phase, as has been reported by Yan et al. (2016). This is possibly because the $\mathrm{Pb}$ released from organic complexes precipitate at the intestinal $\mathrm{pH}$ (Ruby et al. 1993, 1999, Li et al. 2014). However, Pb (II) can be bio-transformed, modifying its solubility and toxicity (Calatayud and Llopis 2015, Cangelosi et al. 2017).

An increase of $\mathrm{Pb}$ bioaccessibility in the intestinal phase can enhance its toxicity. According to Kan et al. (2017), the Pb carbonates' transformation to soluble organic $\mathrm{Pb}$-complexes at neutral $\mathrm{pH}$ explain the increase of $\mathrm{Pb}$ bioaccessibility.

The bioaccessibility data for NIST 2710 in the gastric phase with the GSRSB- PBET method was more precise than with NOM-147, but this tendency is not clearly observed in the composite samples as mentioned above (Table II). Nevertheless, all the
As and $\mathrm{Pb}$ values fall into the in vivo range reported by Koch et al. (2013) (Fig. 3), indicating that the reagents - and possibly the novel reactor system that reduces soil particle erosion and provides easier $\mathrm{pH}$ control- improve results.

In addition to those reported by several laboratories (Koch et al. 2013), all the data obtained in this study in the intestinal phase were lower than the in vivo range. It is worth mentioning that, according to Dabin et al. (2012), the in vitro methods with results similar to "in vivo" have longer agitation times or use more violent shakers. Therefore, it is possible that the intestinal phase results obtained with the GSRSB-PBET method can be improved by increasing agitation time.

\section{CONCLUSIONS AND RECOMMENDATIONS}

The PBET method using the novel reactor system (GSRSB) provides easier $\mathrm{pH}$ control, and gastric phase data are more precise (\% RSD) than the standard Mexican NOM-147 method.

The NIST 2710 results using the GSRSB-PBET method with the novel reactor show no statistical difference with respect to the in vivo measurements in the gastric phase.

The NOM-147 method measuring As and $\mathrm{Pb}$ bioaccessibility in the gastric phase does not simulate in vivo values and seems to overestimate the associated risk. Therefore, GSRSB-PBET method could be considered a precise alternative to measure As and $\mathrm{Pb}$ bioaccessibility in polluted soils modifying NOM-147 method and including the bioaccessibility measurement of other elements, mainly As.

The bioaccessibility of $\mathrm{Pb}$ measured during the intestinal phase (PBET) is always lower than in the gastric phase using both methods. Nevertheless, As behavior is the opposite except in $\mathrm{C} 3$, the only basic sample. It is recommended to include both phases and not only the gastric. It can also be possible to use the highest bioaccessibility value from both phases or perform in vivo bioavailability measurements.

Nevertheless, variability in soil results within the same metallurgical complex poses a challenge: to identify a general method with which to measure bioaccessibility in all types of contaminated soils, simulating in vivo data. Thus, it is essential to perform a complementary study to measure the bioaccessibility of a higher number of previously characterized soils. It must include at least the two studied methods and the two agitation systems with different agitation times and in vivo bioavailability determination. 


\section{ACKNOWLEDGMENTS}

We thank Daniel Amaro-Ramírez and Leticia Pérez-Manzanera for general support. The authors acknowledge Gerardo Martínez-Jardines and Teresa Pi-Puig (Instituto de Geología, UNAM) for technical support. T. García-Rodríguez is thankful to CONACYT Mexico for the fellowship received to perform Ph.D. studies.

\section{REFERENCES}

Agency for Toxic Substances and Disease Registry (ATSDR) (2007). Toxicological profile for arsenic. Atlanta, GA: U.S. Department of Health and Human Services, Public Health Service. https://doi. org/10.15620/cdc:11481

Alcaraz-Contreras Y., Garza-Ocanas L., Carcaño-Díaz K. and Ramírez-Gómez X.S. (2011). Effect of glycine on lead mobilization, lead-induced oxidative stress, and hepatic toxicity in rats. J. Toxicol. https://doi. org/10.1155/2011/430539

ASTM (2006). Standard Test Method for Shake Extraction of Solid Waste with Water, ASTM D3987-06. American Standards Testing and Materials International, West Conshohocken, PA. www.astm.org. https://doi. org/10.1520/D3987-06

Aoki S., Masamitsu K. and Yasuo A. (1984). Behavior of granulated blast furnace slag in hydrochloric acid solution._Gypsum \& lime 1984 (191), 200-208. https:// doi.org/10.11451/mukimate1953.1984.200

Borch T., Kretzschmar R., Kappler A., Cappellen P.V., Ginder-Vogel M., Voegelin A. and Campbell K. (2010). Biogeochemical redox processes and their impact on contaminant dynamics. Environ. Sci. Technol. 44 (1), 15-23. https://doi.org/10.1021/es9026248

Bradham K.D., Scheckel K.G., Nelson C.M., Seales P.E., Lee G.E., Hughes M. F., Miller B.W., Yeow A., Gilmore T., Harper S. and Thomas D.J. (2011). Relative bioavailability and bioaccessibility and speciation of arsenic in contaminated soils. Environ. Health Perspect. 119 (11), 1629-1634. https://doi.org/10.1289/ehp.1003352.

Bremner J.M. and Tabatabai M.A. (1971). Use of automated combustion techniques for total carbon, total nitrogen, and total sulfur analysis of soils. Instrumental methods for analysis of soils and plant tissue 1-15. https://doi.org/10.2136/1971.instrumentalmethods.c1

Calatayud M. and Llopis J.M.L. (2015). Arsenic through the gastrointestinal tract. In: Handbook of Arsenic Toxicology (S.J.S. Flora, Ed.), Academic Press, pp. 281-299. https://doi.org/10.1016/B978-0-12-418688$0.00010-1$
Cangelosi V., Ruckthong L. and Pecoraro V.L. (2017). Lead (II) binding in natural and artificial proteins. Metal ions in life sciences 17. https://doi. org/10.1515/9783110434330-010

Chiodo L.M., Jacobson S.W. and Jacobson J.L. (2004). Neurodevelopmental effects of postnatal lead exposure at very low levels. Neurotoxicol. Teratol. 26 (3), 359371. https://doi.org/10.1016/j.ntt.2004.01.010

CLIMATE-DATA (2021). Climate of San Luis Potosí, México [online]. https://es.climate-data.org/americadel-norte/mexico/san-luis-potosi-22/ 01/04/2021

Conrad M.E. and Barton J.C. (1978). Factors affecting the absorption and excretion of lead in the rat. Gastroenterology 74 (4), 731-740. https://doi.org/10.1016/00165085(78)90253-6

Dabin C., Guigonnet-Sergent A., Algros E. and Charissou A.M. (2012). Bioavailability and bioaccessibility of pollutants in contaminated soils: State of present knowledge and research avenues. RECORD REseau COopératif de Recherche sur les Déchets (Cooperative Research Network on Waste and the Environment). Final report no. 10-0671/1A. https://www.record-net. org/storage/etudes/10-0671-1A/rapport/Rapport_record10-0671 1A.pdf

Denys S., Caboche J., Tack K., Rychen G., Wragg J., Cave M., Jondreville C. and Feidt C. (2012). In vivo validation of the unified BARGE method to assess the bioaccessibility of arsenic, antimony, cadmium, and lead in soils. Environ Sci. Technol. 46(11), 6252-6260. https://doi.org/10.1021/es3006942

Diamond G.L., Goodrum P.E., Felter S.P. and Ruoff W.L. (1998). Gastrointestinal absorption of metals. Drug Chem. Toxicol. 21(2), 223-251. https://doi. org/10.3109/01480549809011649

Donahoe R.J., Yang L. and Lanzirotti A. (2005). Speciation and surface complexation of as on hydrous ferric oxide in soils modified by in situ chemical fixation. Geochim. Cosmochim. Acta 69(10), A616. Bibcode: 2005GeCAS..69..616D

Drexler J.W. and Brattin W.J. (2007). An in vitro procedure for estimation of lead relative bioavailability: with validation. Hum. Ecol. Risk Assess. 13(2), 383-401. https://doi.org/10.1080/10807030701226350

Elsheikh M.A., Muchaonyerwa P., Johan E., Matsue N. and Henmi T. (2018). Mutual adsorption of lead and phosphorus onto selected soil clay minerals. Adv. Chem. Eng. Sci. 8(2), 67-81. https://doi.org/10.4236/aces.2018.82005

Flynn C.M. (1984). Hydrolysis of inorganic iron (III) salts. Chem. Rev. 84(1), 31-41. https://doi.org/10.1021/ cr00059a003

Freeman G.B., Johnson J.D., Liao S.C., Feder P.I., Davis A.O., Ruby M.V. and Bergstrom P.D. (1994). Absolute bioavailability of lead acetate and mining waste 
lead in rats. Toxicol. 91(2), 151-163. https://doi. org/10.1016/0300-483X(94)90141-4

Frey Bruce Ed. (2018). Judgment sampling. In: The SAGE Encyclopedia of Educational Research, Measurement and Evaluation. http://dx.doi. org/10.4135/9781506326139.n367

García-Rodríguez T. (2013). Estudio de la bioaccesibilidad de arsénico, cadmio y plomo en suelos impactados con residuos mineros. Bachelor Dissertation. Facultad de Química, Universidad Nacional Autónoma de México (UNAM). Ciudad de México, México, 188 pp.

García-Rodríguez T. (2017). Estudio de los factores que influyen en la precisión de la prueba de bioaccesibilidad de arsénico en suelos contaminados. Master Dissertation. Earth Sciences Program. Universidad Nacional Autónoma de México (UNAM). Ciudad de México, México, 152 pp.

García-Villa M. (2016). Lixiviación de concentrado de plomo tostado en medio de ácido orgánico. Bachelor Dissertation. Facultad de Ingeniería. Universidad Nacional Autónoma de México (UNAM). Ciudad de México, México, 54 pp.

Goldberg S. (2002). Competitive adsorption of arsenate and arsenite on oxides and clay minerals. Soil Sci. Soc. Am. J. 66(2), 413-421. https://doi.org/10.2136/ sssaj2002.4130

González-Grijalva B., Meza-Figueroa D., Romero F.M., Robles-Morúa A., Meza-Montenegro M., García-Rico L. and Ochoa-Contreras R. (2019). The role of soil mineralogy on oral bioaccessibility of lead: Implications for land use and risk assessment. Sci. Total Environ. 657, 1468-1479. https://doi.org/10.1016/j. scitotenv.2018.12.148

Gutiérrez-Ruiz M.E., Ceniceros-Gómez A.E., Villalobos M., Romero F. and Santiago P. (2012). Natural arsenic attenuation via metal arsenate precipitation in soils contaminated with metallurgical wastes: II. Cumulative evidence and identification of minor processes. Appl. Geochem. 27(11), 2204-2214. https://doi. org/10.1016/j.apgeochem.2012.02.021

Gutiérrez-Ruiz M.E., Romero F.M., González Chávez J.L., Santos Jallath J.E., Martínez Jardines G. y 11 colaboradores. (2003). Diagnóstico ambiental de la planta de cobre, S.L.P. Laboratorio de Análisis Físicos y Químicos del Ambiente. Grupo MéxicoIndustrial Minera México. Instituto de Geografía, Universidad Nacional Autónoma de México (UNAM) México

Hernández-Mendiola E., Romero F.M., Gutiérrez-Ruiz M. and Rico C.A.M. (2016). Solid phases controlling the mobility of potentially toxic elements and the generation of acid drainage in abandoned mine gold wastes from San Antonio-El Triunfo mining district, Baja
California Sur, México. Environ. Earth Sci. 75(11), 969. https://doi.org/10.1007/s12665-016-5755-6

Hesse P.R. (1971). A textbook of soil chemical analysis. John Murray, London, Great Britain, Chap. 2 pp. 10-17.

IARC (2006). Summaries \& evaluations: Inorganic and organic lead compounds. Lyon, International Agency for Research on Cancer. Monographs for the Evaluation of Carcinogenic Risks to Humans, 87.

ISO (2005). Soil quality-determination of $\mathrm{pH}$. Method 10390:2005. International Organization for Standardization. Manual. Geneva, Switzerland, 7 pp.

Juhasz A.L., Weber J., Smith E., Naidu R., Marschner B., Rees M. and Sansom L. (2009). Evaluation of SBRC-gastric and SBRC-intestinal methods for the prediction of in vivo relative lead bioavailability in contaminated soils. Environ. Sci. Technol. 43(12), 4503-4509. https://doi.org/10.1021/es803238u

Juhasz A.L., Smith E., Nelson C., Thomas D.J. and Bradham K. (2014). Variability associated with As in vivoin vitro correlations when using different bioaccessibility methodologies. Environ. Sci. Technol. 48(19), 11646-11653. https://doi.org/10.1021/es502751z

Kan J., Sima J. and Cao X. (2017). Transformation and bioaccessibility of lead induced by steamed bread feed in the gastrointestinal tract. Ecotox. Environ. Safe. 137, 158-164. https://doi.org/10.1016/j.ecoenv.2016.11.025

Koch I., Reimer K.J., Bakker M.I., Basta N.T., Cave M.R., Denys S., Dodd M. and Moore M.M. (2013). Variability of bioaccessibility results using seventeen different methods on a standard reference material, NIST 2710. J. Environ. Sci. Health A 8(6), 641-655. https://doi.or $\mathrm{g} / 10.1080 / 10934529.2013 .731817$

Kumpiene J., Giagnoni L., Marschner B., Denys S., Mench M., Adriaensen K., Vangronsveld J., Puschenreiter M. and Renella G. (2017). Assessment of methods for determining bioavailability of trace elements in soils: a review. Pedosphere 27(3), 389-406. https:// doi.org/10.1016/S1002-0160(17)60337-0

Lenoble V., Bouras O., Deluchat V., Serpaud B. and Bollinger J.C. (2002). Arsenic adsorption onto pillared clays and iron oxides. J. Colloid. Interf. Sci. 255(1), 52-58. https://doi.org/10.1006/jcis.2002.8646

Li H.B., Cui X.Y., Li K., Li J., Juhasz A.L. and Ma L.Q. (2014). Assessment of in vitro lead bioaccessibility in house dust and its relationship to in vivo lead relative bioavailability. Environ. Sci. Technol. 48(15), 85488555. https://doi.org/10.1021/es501899j

Liu Y., Bello O., Rahman M. M., Dong Z., Islam S. and Naidu R. (2017). Investigating the relationship between lead speciation and bioaccessibility of mining impacted soils and dusts. Environ. Sci. Pollut. Res. 24(20), 17056-17067. https://doi.org/10.1007/s11356017-9250-8 
Magalhães M.C.F. (2002). Arsenic. An environmental problem limited by solubility. Pure Appl. Chem. 74(10), 1843-1850. https://doi.org/10.1351/pac200274101843

Mandal B.K. and Suzuki K.T. (2002). Arsenic round the world: a review. Talanta 58(1), 201-235. https://doi. org/10.1016/S0039-9140(02)00268-0

Martínez-Jardines L.G. (2018). Barreras geoquímicas y estabilización físico-química para el manejo ambientalmente seguro de residuos metalúrgicos y suelos contamiandos con arsénico y metales pesados en San Luis Potosí. PhD Dissertation. Earth Sciences Program. Universidad Nacional Autónoma de México (UNAM). Ciudad de México, México, 271 pp.

Masindi V. and Muedi K.L. (2018). Environmental contamination by heavy metals. Heavy metals 10, 115-132. http://dx.doi.org/10.5772/intechopen.76082

Mason L.H., Harp J.P. and Han D.Y. (2014). Pb neurotoxicity: neuropsychological effects of lead toxicity. Bio. Med. Res. Int. 2014. https://doi.org/10.1155/2014/840547

Mitra P., Sharma S., Purohit P. and Sharma P. (2017). Clinical and molecular aspects of lead toxicity: An update. Crit. Rev. Clin. Lab. Sci. 54(7-8), 506-528. https://doi. org/10.1080/10408363.2017.1408562

Mushak P. (1991). Gastro-intestinal absorption of lead in children and adults: overview of biological and biophysico-chemical aspects. Chem. Spec. Bioavailab. 3(3-4), 87-104. https://doi.org/10.1080/09542299.199 1.11083160

Nazer A., Paya Bernabeu J.J., Borrachero Rosado M.V. and Monzó Balbuena J.M. (2016). Caracterización de escorias de cobre de fundiciones chilenas del Siglo XIX. Rev. Metal. 52 (4). https://doi.org/10.3989/revmetalm.083

NIST (2003. Certificate of Analysis, Standard Reference Material ${ }^{\circledR} 2710$ Montana Soil, Highly Elevated Trace Element Concentrations. National Institute of Standards and Technology: Gaithersburg, MD, USA, pp. 1-6.

Ollson C.J., Smith E., Herde P. and Juhasz A.L. (2017). Influence of co-contaminant exposure on the absorption of arsenic, cadmium and lead. Chemosphere 168, 658-666. https://doi.org/10.1016/j.chemosphere.2016.11.010

Panayotova M. (2016). Mining and mineral processing as heavy metals pollution source. In: Heavy metals, sources, toxicity and remediation techniques (D. Pathania Ed.). Series: Materials Science and Technologies. Nova Publisher. New York, USA. Chapter 3, pp. 59101. https://novapublishers.com/shop/heavy-metalssources-toxicity-and-remediation-techniques/

Pokrovski G.S., Kara S. and Roux J. (2002). Stability and solubility of arsenopyrite, FeAsS, in crustal fluids. Geochim. Cosmochim. Acta 66(13), 2361-2378. https://doi.org/10.1016/S0016-7037(02)00836-0
Quiroz-Vivanco D. (2018). Diseño de un equipo para realizar pruebas y análisis de bioaccesibilidad de metales en suelos. Bachelor dissertation (Chemical Engineering). Facultad de Química, Universidad Nacional Autónoma de México (UNAM). Ciudad de México, México, 143 pp.

Romero F.M., Villalobos M., Aguirre R. and Gutierrez M.E. (2008). Solid-phase control on lead bioaccessibility in smelter-impacted soils. Arch. Environ. Contam. Toxicol. 55(4), 566-575. https://doi.org/10.1007/ s00244-008-9152-3

Rooney C.P. (2002). The fate of lead in soils contaminated with lead shot (Doctoral dissertation, Lincoln University). http://researcharchive.lincoln.ac.nz/ handle/10182/1440

Ruby M.V., Davis A., Link T.E., Schoof R., Chaney R.L., Freeman G.B. and Bergstrom P. (1993). Development of an in vitro screening test to evaluate the in vivo bioaccessibility of ingested mine-waste lead. Environ. Sci. Technol. 27(13), 2870-2877. https://doi.org/10.1021/ es00049a030

Ruby M.V., Davis A., Schoof R., Eberle S. and Sellstone C.M. (1996). Estimation of lead and arsenic bioavailability using a physiologically based extraction test. Environ. Sci. Technol. 30(2), 422-430. https://doi. org/10.1021/es950057z

Ruby M.V., Schoof R., Brattin W., Goldade M., Post G., Harnois M. and Edwards D. (1999). Advances in evaluating the oral bioavailability of inorganics in soil for use in human health risk assessment. Environ. Sci. Technol. 33(21), 3697-3705. https://doi.org/10.1021/es990479z

Sattar A., Xie S., Hafeez M.A., Wang X., Hussain H.I., Iqbal Z. and Yuan Z. (2016). Metabolism and toxicity of arsenicals in mammals. Environ. Toxicol. Pharmacol. 48, 214-224. https://doi.org/10.1016/j.etap.2016.10.020

Schnaas L., Rothenberg S. J., Flores M.F., Martinez S., Hernandez C., Osorio E. and Perroni E. (2006). Reduced intellectual development in children with prenatal lead exposure. Environ. Health Perspect. 114(5), 791-797. https://doi.org/10.1289/ehp.8552

SEMARNAT (2007). Norma Oficial Mexicana NOM147/SSA1-2004. Criterios para determinar las concentraciones de remediación de suelos contaminados por arsénico, bario, berilio, cadmio, cromo hexavalente,mercurio, níquel, plata, plomo, selenio, talio y/o vanadio. Secretaría de Medio Ambiente y Recursos Naturales. Diario Oficial de la Federación. Poder Ejecutivo Federal. 2 de marzo de 2007.

Sidhu P.S., Gilkes R.J., Cornell R.M., Posner A.M. and Quirk J.P. (1981). Dissolution of iron oxides and oxyhydroxides in hydrochloric and perchloric acids. Clays Clay Miner. 29(4), 269-276. https://doi.org/10.1346/ CCMN.1981.0290404 
Simon D.E. and Anderson M.S. (1990). Stability of clay minerals in acid. In SPE Formation Damage Control Symposium. Society of Petroleum Engineers. https:// doi.org/10.2118/19422-MS

Singh A.P., Goel R.K. and Kaur T. (2011). Mechanisms pertaining to arsenic toxicity. Toxicol. International 18(2), 87-93. https://www.ncbi.nlm.nih.gov/pmc/ articles/PMC3183630/

Smedley P.L. and Kinniburgh D.G. (2002). A review of the source, behaviour and distribution of arsenic in natural waters. Appl. Geochem. 17(5), 517-568. https://doi. org/10.1016/S0883-2927(02)00018-5

Sposito G. (2008). The chemistry of soils. 2nd. ed. Oxford University Press. New York, USA, pp. 329. https:// global.oup.com/academic/product/the-chemistry-ofsoils-9780190630881?cc $=\mathrm{mx} \&$ lang $=\mathrm{en} \&$

USAEC (2003). Guide for incorporating bioavailability adjustments into human health and ecological risk assessments at US Department of Defense Facilities. Part 2: Technical background document for assessing metals bioavailability. US Army Environmental Center. Battelle, Columbus, Ohio. Updated by Dr. Rosalind Schoof. USA, pp. 1-2, 2-1. https://usaphcapps.amedd. army.mil/erawg/DoD\%20Metals\%20Bioavailability $\% 20$ Guide.pdf

USEPA(2000). EPA Method 6010C (SW-846): Inductively Coupled Plasma - Atomic Emission Spectrometry. Revision 3. United States Environmental Protection Agency. Washington, D.C. USA. 30 pp. November 2000. https://19january2017snapshot.epa.gov/sites/ production/files/2015-07/documents/epa-6010c.pdf. Date accessed: November 20, 2020.

USEPA (2007). EPA Method 6200 : Field Portable $\mathrm{X}$-Ray Fluorescence Spectrometry for the Determination of Elemental Concentrations in Soil and Sediment. United States Environmental Protection Agency. Washington, D.C. USA. 32 pp. February 2007. https://www.epa.gov/sites/production/ files/2015-12/documents/6200.pdf. Date accessed: November 20, 2020.

USEPA (2007b). EPA Test Method 3051A (SW-846): Microwave Assisted Acid Digestion of Sediments, Sludges, Soils, and Oils. Revision 1, United States Environmental Protection Agency. Washington, D.C. USA. 30 pp. February 2007. https:/www.epa.gov/ sites/production/files/2015-12/documents/3051a.pdfDate accessed: November 20, 2020.

USEPA (2012). Compilation and Review of Data on Relative Bioavailability of Arsenic in soil. US Environmental Protection Agency, OSWER 9200.1-113., Washington, D.C. USA. 58 pp. December 2012. https://semspub.epa.gov/work/HQ/175339.pdf. Date accessed: November 20, 2020.
Villa L.C., Agudelo W.S. and Rojas N.R. (2018). Estudio termodinámico de la lixiviación de plomo reciclado con citrato de sodio. Cienc. Desarro. 9(2), 119-126. https://doi.org/10.19053/01217488.v9.n2.2018.7262

Villalobos M., García-Payne D.G., López-Zepeda J.L., Ceniceros-Gómez A.E. and Gutiérrez-Ruiz M.E. (2010). Natural arsenic attenuation via metal arsenate precipitation in soils contaminated with metallurgical wastes: I. Wet chemical and thermodynamic evidences. Aquat. Geochem. 16(2), 225-250. https://doi. org/10.1007/s10498-009-9065-4

Villa-Vargas L.C. (2017). Análisis comparativo de agentes lixiviantes orgánicos para el reciclaje de plomo a partir de baterías de automóvil. Master Dissertation. Facultad de Minas, Departamento de Materiales y Minerales, Universidad Nacional de Colombia. Medellín, Colombia.

Walraven N., Bakker M., Van Os B.J.H., Klaver G.T., Middelburg J.J. and Davies G.R. (2015). Factors controlling the oral bioaccessibility of anthropogenic $\mathrm{Pb}$ in polluted soils. Sci. Total Environ. 506, 149-163. https://doi.org/10.1016/j.scitotenv.2014.10.118

Wang S. and Mulligan C.N. (2006). Occurrence of arsenic contamination in Canada: sources, behavior and distribution. Sci. Total Environ. 366(2-3), 701-721. https:// doi.org/10.1016/j.scitotenv.2005.09.005

Ward N.J., Sullivan L.A., Fyfe D.M., Bush R.T. and Ferguson A.J. (2004). The process of sulfide oxidation in some acid sulfate soil materials. Soil Res. 42(4), 449-458. https://doi.org/10.1071/SR03135

Whitfield P. and Mitchell L. (2008). Phase Identification and Quantitative Methods. In: Principles and applications of powder diffraction (A. Clearfield, J.H. Reibenspies and N. Bhuvanesh, Eds..) John Wiley and Sons. New Jersey, USA. Chap. 66, pp. 226-260. https://onlinelibrary.wiley.com/doi/ book/10.1002/9781444305487

Yan K., Dong Z., Liu Y. and Naidu R. (2016). Quantifying statistical relationships between commonly used in vitro models for estimating lead bioaccessibility. Environ. Sci. Pollut. Res. 23(7), 6873-6882. https:// doi.org/10.1007/s11356-015-5947-8

Yin H., Feng X., Qiu G., Tan W. and Liu F. (2011). Characterization of Co-doped birnessites and application for removal of lead and arsenite. J. Hazard. Mater. 188(1-3), 341-349. https://doi.org/10.1016/j. jhazmat.2011.01.129

Zamora Martínez O., Romero F.M and Lozano Santa Cruz R. (2008) Evaluación del desempeño de un analizador portátil de Fluorescencia de Rayos X en la determinación de la composición elemental de residuos mineros. Memorias de la Reunión Anual de la Unión Geofísica Mexicana, Pto. Vallarta, Jalisco, Mexico. GEPQP-9, Geos 28(2):161-162. 
Zhang H. and Selim H.M. (2005). Kinetics of arsenate adsorption- desorption in soils. Environ. Sci. Technol. 39(16), 6101-6108. https://doi.org/10.1021/es050334u

Zhang S., Yang D., Wang C., Tian F.R. and Cheng Z. (2011). The synthesis and characterization of glycine-lead. 2011 Second International Conference on Mechanic Automation and Control Engineering pp. 2769-2771. Shuqin Zhang, Dan Yang, Cui Wang, Fu-rong Tian and Zhen Cheng, "The synthesis and characterization of glycine-lead," 2011 Second International Conference on Mechanic Automation and Control Engineering, pp. 2769-2771, doi: 10.1109/MACE.2011.5987559.. https://doi.org/10.1109/MACE.2011.5987559

Zhu X., Yang F. and Wei C. (2015). Factors influencing the heavy metal bioaccessibility in soils were site dependent from different geographical locations. Environ. Sci. Pollut. Res. 22(18), 13939-13949. https:// doi.org/10.1007/s11356-015-4617-1 